\title{
No general shift in spring migration phenology by eastern North American birds since 1970
}

\author{
André Desrochers Département des sciences du bois et de la forêt, Université Laval, Québec, Canada \\ Andra Florea Observatoire d'oiseaux de Tadoussac, Québec, Canada \\ Pierre-Alexandre Dumas Observatoire d'oiseaux de Tadoussac, Québec, Canada, and Département des sci- \\ ences du bois et de la forêt, Université Laval, Québec, Canada
}

We studied the phenology of spring bird migration from eBird and ÉPOQ checklist programs South of $49^{\circ} \mathrm{N}$ in the province of Quebec, Canada, between 1970 and 2020. 152 species were grouped into Arctic, long-distance, and short-distance migrants. Among those species, 75 significantly changed their migration dates, after accounting for temporal variability in observation effort, species abundance, and latitude. But in contrast to most studies on the subject, we found no general advance in spring migration dates, with 36 species advancing and 39 species delaying their migration. Several early-migrant species associated to open water advanced their spring migration, possibly due to decreasing early-spring ice cover in the Great Lakes and the St-Lawrence river since 1970. Arctic breeders and short-distance migrants advanced their first arrival dates more than long-distance migrants not breeding in the arctic. However, there was no difference among migrant groups when median arrival dates were considered. We conclude that general claims about advances in spring migration dates in eastern North America are misleading due to large taxonomic variation.

Keywords: Birds, eBird, Migration, Climate change, Phenology, North America

\section{Introduction}

Spring migration in birds is triggered by a combination of physiological, astronomical, and climate factors (Gwinner, 2003; Newton, 2008). Astronomical and physiological phenomena do not vary at the decadal scale, but climate and weather do, with substantial variation at the regional level (IPCC, 2013). With the rising awareness of climate change, ornithologists have focused on its possible effects on avian ecology, especially migration phenology (Berthold, 1991), ensuing ecological mismatches (Both and Visser, 2001; Thomas et al., 2001; Saino et al., 2009), and their possible consequences on populations (Møller et al., 2008; Both et al., 2006). Warmer weather is generally thought to advance spring migration, e.g. by reducing the risk of late frosts and increasing food availability early in the season due to changing plant and arthropod phenology (Gordo, 2007). As a result of the accumulating studies on the subject, the Intergovernmental Panel on Climate Change (IPCC) gave "high confidence" in the claim about a general spring advancement of migration in the northern hemisphere (Settele et al., 2014). Some authors went further and labeled this phenomenon as a 'flagship example of the biological impacts of climate change' (Kelly et al., 2017), and one of the best documented biological responses to climate change (e.g. Miller-Rushing et al., 2008; Newson et al., 2016).

Early evidence for the advancement of spring migration came mostly from numerous smallscale studies, conducted mostly in Europe (Gienapp et al., 2007; Leech and Crick, 2007). A close examination of those studies shows that the changes in spring migration dates are not as straightforward as implied by the above claims. For example, Lehikoinen (2004) found that of 222 time series, only $26 \%$ exhibited significantly advancing mean migration dates. Most time series (69\%) 
exhibited no pattern and $5 \%$ showed delayed migration. A more recent review based on 440 time series of mean or median arrival dates for 214 species also suggested a great variability in trends, with evidence for an advancement (28\% of the species), no change (51\%) and a delay (21\%) in spring migration dates [Lehikoinen and Sparks (2010); Fig. 9.4]. Knudsen et al. (2011) reviewed ten inferences made about phenological patterns in migration from recent decades, and Chmura et al. (2019) provided a detailed review of mechanistic hypotheses for those patterns. Most of these studies associated phenological changes to the warming climate of recent decades, because the former "is consistent with" the latter. But empirical evidence for this causal inference is often questionable, due to the presence of several sources of variation such as species life-history, geographic region, and age distribution (Knudsen et al., 2011). Knudsen et al. (2011) point out that because species differ in their movements and ecology, and because climate change varies geographically, we should not expect changes in migration phenology to be globally similar, but to be associated to regions as well as aspects of species ecology such as the location of their wintering grounds (Hüppop and Hüppop, 2011).

Despite the large number of migration phenology studies, empirical gaps in our understanding of regional variation still greatly limit our ability to understand spatio-temporal patterns, not to mention their causes and consequences. Those gaps do not come only from uneven sampling effort, but also from methodological misconceptions. Temporal changes in sampling effort (MillerRushing et al., 2008; Moussus et al., 2010) or bird abundance (Miller-Rushing et al., 2008; Tryjanowski et al., 2005; Sparks, 1999; Koleek et al., 2020) are known to bias trend estimates. This problem has been recognized by several authors (e.g., Moussus et al., 2010; Gordo, 2007; Goodenough et al., 2015), especially when extreme values such as first arrivals or low quantiles are used. The latter studies recognize the advantages of mean or median arrival dates, less sensitive to sampling effort and population size. Nevertheless, first, or early arrival dates continue to dominate the empirical basis for multi-decadal changes in spring migration (Tryjanowski et al., 2005; Knudsen et al., 2011). Despite its inherent sensitivity to sampling bias, abundance and the cumulative distribution of arrivals (Sparks et al., 2001), first arrival dates are worth examining in addition to central estimates such as medians and means, because changing strategies of early individuals may inform us about the plasticity of the species to changing environmental conditions (Mathot et al., 2012).

Another problem is the lack of reliable multi-decadal records outside those obtained from standardized migration counts at long-established bird observatories, mostly located in Europe. The advent of citizen science programs such as eBird (Sullivan et al., 2009) enable us to monitor changes in bird behaviour and populations in seasons usually not covered by standardised longterm programs such as the Breeding Bird Survey (Sauer et al., 2014) and the Christmas Bird Count (Butcher et al., 1990). Furthermore, citizen science offers a wider geographic coverage than previously available. As a result, it is possible to examine relationships between spring arrival dates in the North, and departure dates from wintering areas.

Here, we investigate whether timing of avian spring migration changed over the last 51 years (1970-2020), in Quebec, Canada, based on eBird (Sullivan et al., 2009) and Étude des populations d'oiseaux du Québec (ÉPOQ; Cyr and Larivée, 1979, 1993) checklist programs. We also test the relationship between migration phenology and migration distances, the latter obtained from January and February eBird records of each species. Finally, we assess whether variation in arrival dates of early species is greater than that of later-arriving species. 


\section{Methods}

We downloaded data from the February 2021 release of the eBird (eBird Basic Dataset, 2021) and ÉPOQ (Cyr and Larivée, 1979, 1993) datasets. Together, those datasets totalled 3,933,296 records for retained species between springs 1970 and 2020, between 1 March and 10 June. Since the launch of eBird, annual reported effort by Quebec birders has increased exponentially from 2,571 h (1970) to 114,840 h (2020; Fig. 1).

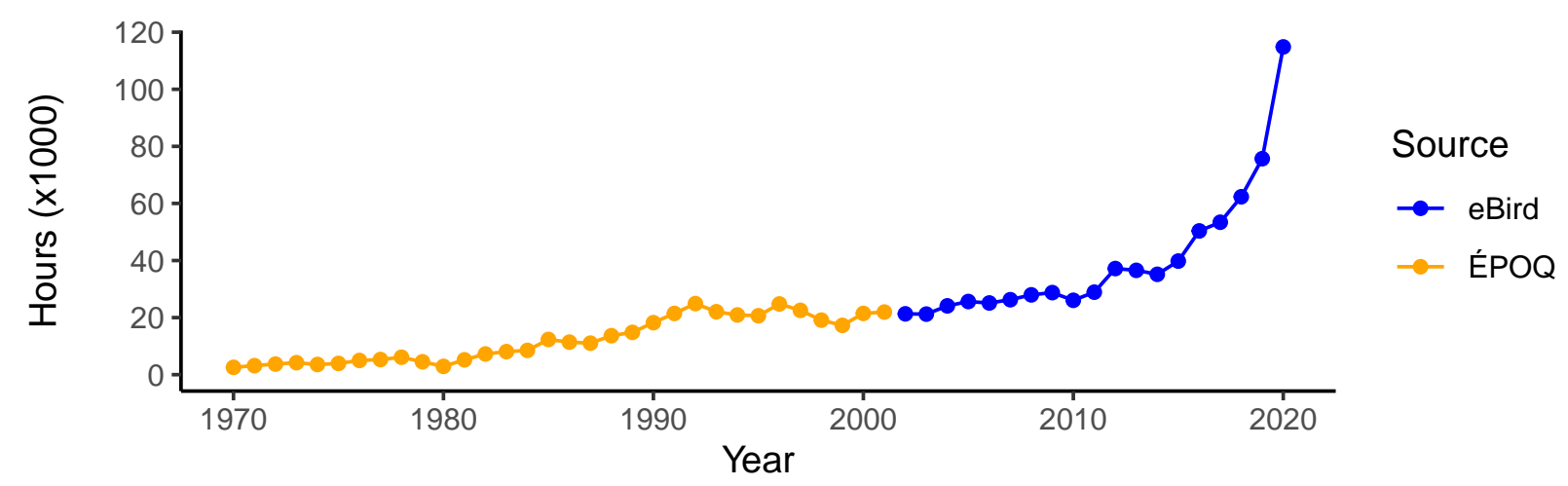

Figure 1: Observation effort (1 March - 10 June) from ÉPOQ and eBird checklist programs, south of $49^{\circ} \mathrm{N}$, Quebec, Canada.

\section{Data preparation}

We omitted data before 1 January 1970 from the analysis, because of small sample sizes. We also omitted data North of $49^{\circ} \mathrm{N}$ to reduce statistical noise due to latitudinal effects on bird arrival dates. Finally, we excluded all records before 1 March or after 10 June to reduce the influence of records of wintering or breeding birds. We selected species that were found in $>0.1 \%$ of complete eBird lists, and whose records between 15 December and 15 February represented $<1 \%$ of the species' records.

We classified species into three groups based on migration distance: short-distance, longdistance, and Arctic migrants (Appendix). For short- and long- distance migrants, we extracted all midwinter (January and February) eBird records, between longitudes -100 and -30 , i.e. covering Eastern North America and Latin America. We calculated maximum daily counts for each unique combination of species, latitude and longitude (1-degree squares), and date, and calculated mean midwinter coordinates weighted by the sum of daily counts. Short-distance migrants were species whose majority of individuals recorded in midwinter were north of $28^{\circ} \mathrm{N}$, roughly corresponding to the north of the Gulf of Mexico. The other species were classified as long-distance migrants, except species nesting mostly in the Arctic, regardless of their wintering grounds. We made this distinction because the Arctic biomes are regarded as the most affected by climate change (IPCC, 2013). Thus, Arctic breeding species could be more affected by climate change than short or longdistance migrants.

Several indicators can be used to measure bird migration phenology, each with its own caveats (Moussus et al., 2010). We used two indicators: the first arrival date, and the median arrival date. For first arrival dates, each year we randomly sampled, without replacement, a number of records equal to the lowest number of records in the time series (min. 10) to account for changes in sampling effort and bird abundances, both affecting the number of records and in turn, the 
records' earliest dates. Each year, we retained the earliest date from the random sample, as per Francoeur et al. (2012). We repeated the latter sampling procedure 100 times for each species, and computed the mean of the 100 first arrival date resamples for each year. For median arrival dates, we used Spark's 'median bird' method (Bulmer, 1980), i.e. in the present case, the date at which half of the individuals recorded for the 1 March - 10 June date range were observed. Multiple checklists at the same time and location could duplicate the number of birds. Thus, we aggregated records by locality, date, and species, and retained maximum counts. Besides annual changes in sample size and species abundance, first arrival and median arrival dates could still be biased by annual variation in the timing of observation effort (e.g., early vs. late spring). Thus, we calculated the mean date of checklists each year to measure and account for this potential bias.

\section{Statistical modeling}

We performed the analysis in two steps. First, we generated regression estimates for each species, and second we performed a meta-analysis of the regression estimates across species. For the first step, we used simple Gaussian linear models of arrival dates for each species as a function of year, annual mean effort (checklist) date, and mean checklist latitude as fixed effects. Effort date and latitude were included because of possible biases due to systematic changes in observation dates and locations that may have occurred in the 51 years of the study.

For the second step we tested whether mean regression estimates from step one differed from zero and whether they were associated with migration distance. There may be a substantial phylogenetic effects in migration phenologies (Rubolini et al., 2007). Thus, we used phylogenetically independent linear contrasts (Freckleton et al., 2002; Harvey and Pagel, 1991; Felsenstein, 1985) to account for phylogenetic proximity among the retained species, based on data from Jetz et al. (2012). Because of uncertain relationships between DNA data and years since speciation, phylogenetic trees are only approximations based on assumptions about the rate of phylogenetic divergence. Thus, we generated 100 phylogenetic trees from Jetz et al. (2014) and established phylogenetic distances for each dyad from the 152 species studied (Paradis and Schliep, 2018). We modelled the effects of migratory distance on regression estimates with a linear model using phylogenetic Generalized Least Squares (pGLS). The pGLS method accounts for the phylogenetic distance between species by using a distance covariance matrix which gives more weight to differences between phylogenetically distant species than differences between closely related species (Felsenstein, 1985; Grafen, 1989; Harvey and Pagel, 1991). We ran 100 pGLS models, corresponding to each of the 100 phylogenetic trees of all species. We calculated mean estimates, their standard error and their p-values from the 100 models. We used an error rate of $\alpha=0.05$ for significance statements, with no correction for multiple tests. All data preparation and statistical analyses were performed with R (R Core Team, 2020), with packages ape (Paradis and Schliep, 2018), phylolm (Ho and Ané, 2014) for pGLS, and emmeans for gls multiple comparisons (Lenth, 2021).

\section{Results}

Since 1970, spring observers have been relatively constant in the dates of their observations, with a mean spring effort date advancing by $-1.1 \pm 0.7$ days over the $51-y$ period $(p=0.1)$. After accounting for possible biases due to changing effort dates and latitudes, 75 species significantly changed their spring migration phenology, in terms of first arrival dates (48 spp.) or median arrival dates (52 spp.; see Appendix). However, first or median dates did not generally advance since 1970, (Fig. 2; $\hat{\beta}=-0.041 \pm 0.24$ days per decade, $t=-0.16, \mathrm{df}=148, p>0.9$ ). When first and 


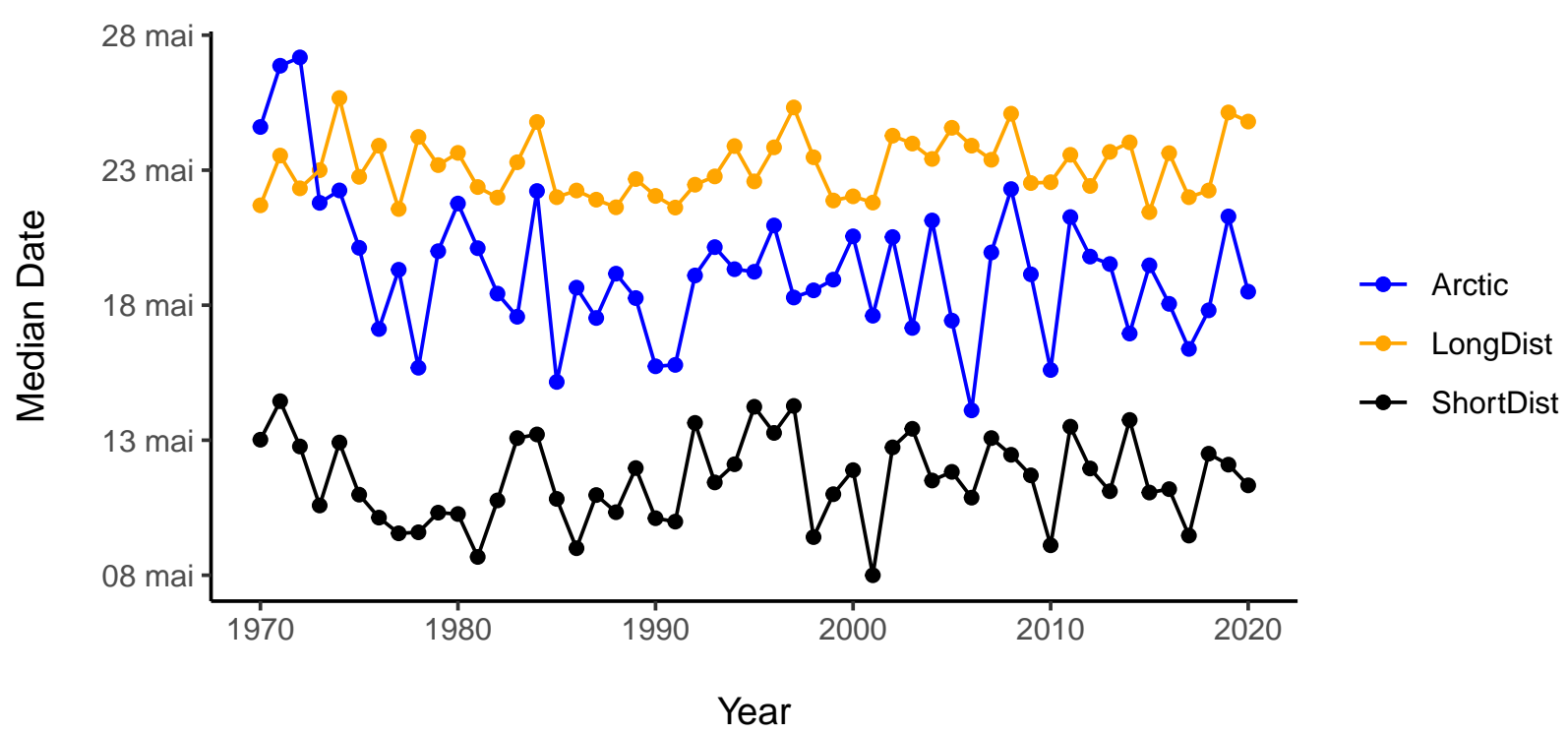

Figure 2: Changes in spring median dates according to migratory distance. Median dates were obtained by averaging species-specific dates at which $50 \%$ of the individuals were recorded.

median dates are combined, 36 species advanced their migration by at least one metric, while 39 delayed their migration.

Based on median dates, 23 of the 149 species investigated showed a significant advance in spring migration, 29 species arrived significantly later since 1970, and 97 did not exhibit change. There was no significant variation of trends among species groups defined by migration distances $(F=0.08, \mathrm{df}=2,146, p=0.93)$. However, it is worth mentioning that the majority of the species that did advance their median arrival date were associated to open water whereas very few $(\sim 5)$ of the later-arriving species fell into this category (Fig. 3).

Similarly to median dates, first arrival dates did not generally advance since 1970, after accounting for bias in checklist dates and latitudes (Fig. 4; $\hat{\beta}=-0.35 \pm 0.46$ days per decade, $t=$ $-0.77, \mathrm{df}=133, p=0.4) .29$ of the 134 species investigated showed a significant advance in spring migration, 19 arrived significantly later since 1970, and 86 did not exhibit change in first arrival date.

There was a significant variation of first arrival trends among migration distances $(F=5.76$, $\mathrm{df}$ $=2,131, p=0.005)$, with long-distance, first arrivals of non-arctic species advancing slower that those of arctic nesters and short-distance migrants (estimated marginal mean contrasts, Tukey method: $p<0.03$ and $p<0.01$ respectively). Trends in first arrival dates of short-distance migrants and arctic nesters did not differ $(p=0.01)$. As was the case with median arrival dates, most of the species that did advance their first arrival dates were associated to open water (Fig. 5).

Spark's 'median bird' (1980) method and our sampling procedure for first arrival dates were designed to remove correlations between trends in arrival dates and sampling effort or species abundances. As expected, we found no significant correlation between arrival dates and species trends over the last 51 years as expressed by changes in the proportion of occupied $10 \mathrm{~km} \times 10 \mathrm{~km}$ squares $(r<0.1, p>0.05$; A. Desrochers, unpubl.data).

Species whose median arrival dates advanced between 1970 and 2020 tended to have earlier first arrival dates as well $(r=0.44, p<0.001, n=132)$. Despite this relationship, there was substantial variation between responses based on the two indicators (Fig. 6). First arrival dates of 
bioRxiv preprint doi: https://doi.org/10.1101/2021.05.25.445655; this version posted May 26, 2021. The copyright holder for this preprint (which

was not certified by peer review) is the author/funder, who has granted bioRxiv a license to display the preprint in perpetuity. It is made available under aCC-BY-NC-ND 4.0 International license.

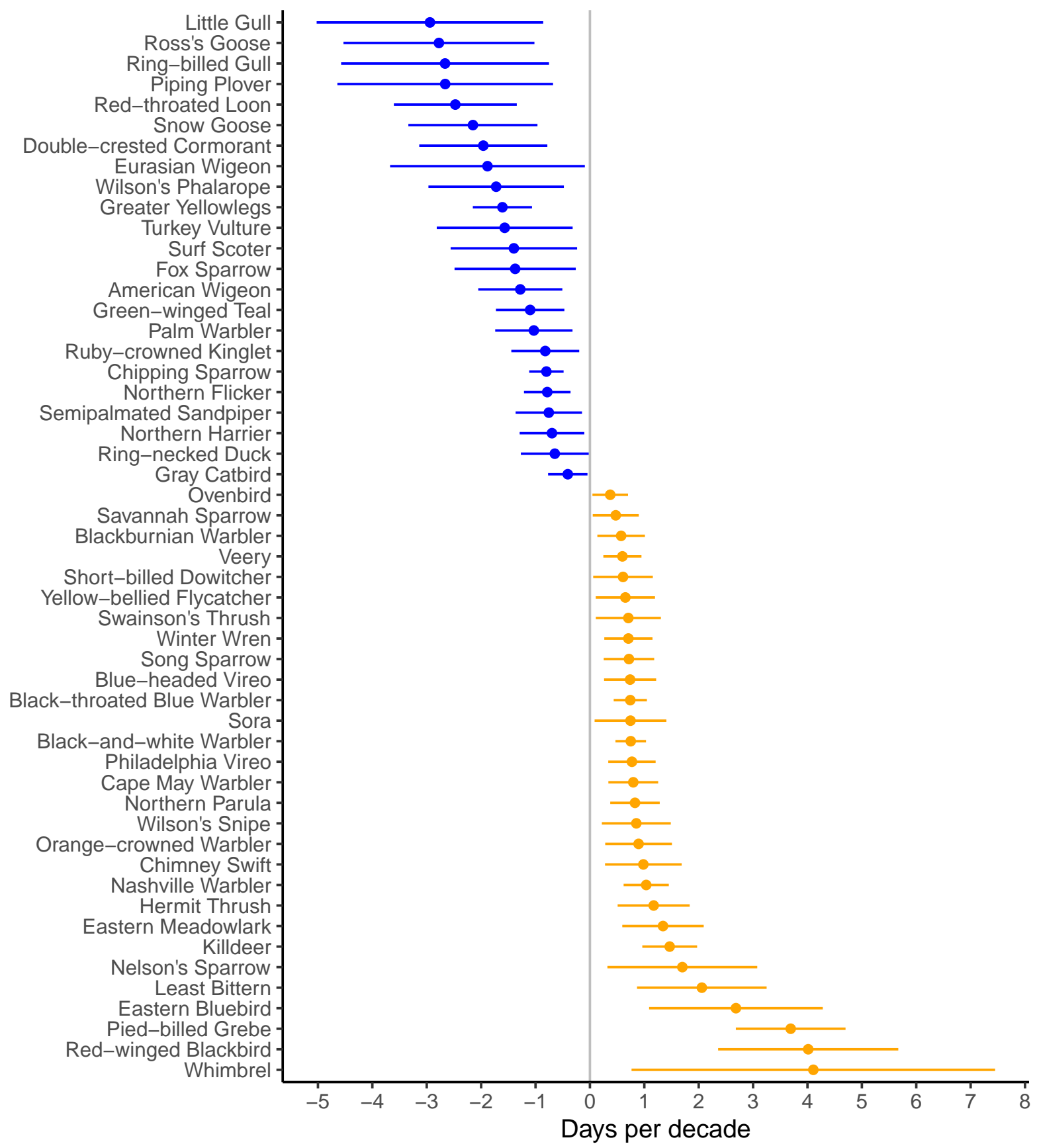

Figure 3: Species with significant 50-year trend in median arrival dates. Bars represent $95 \%$ confidence intervals. 


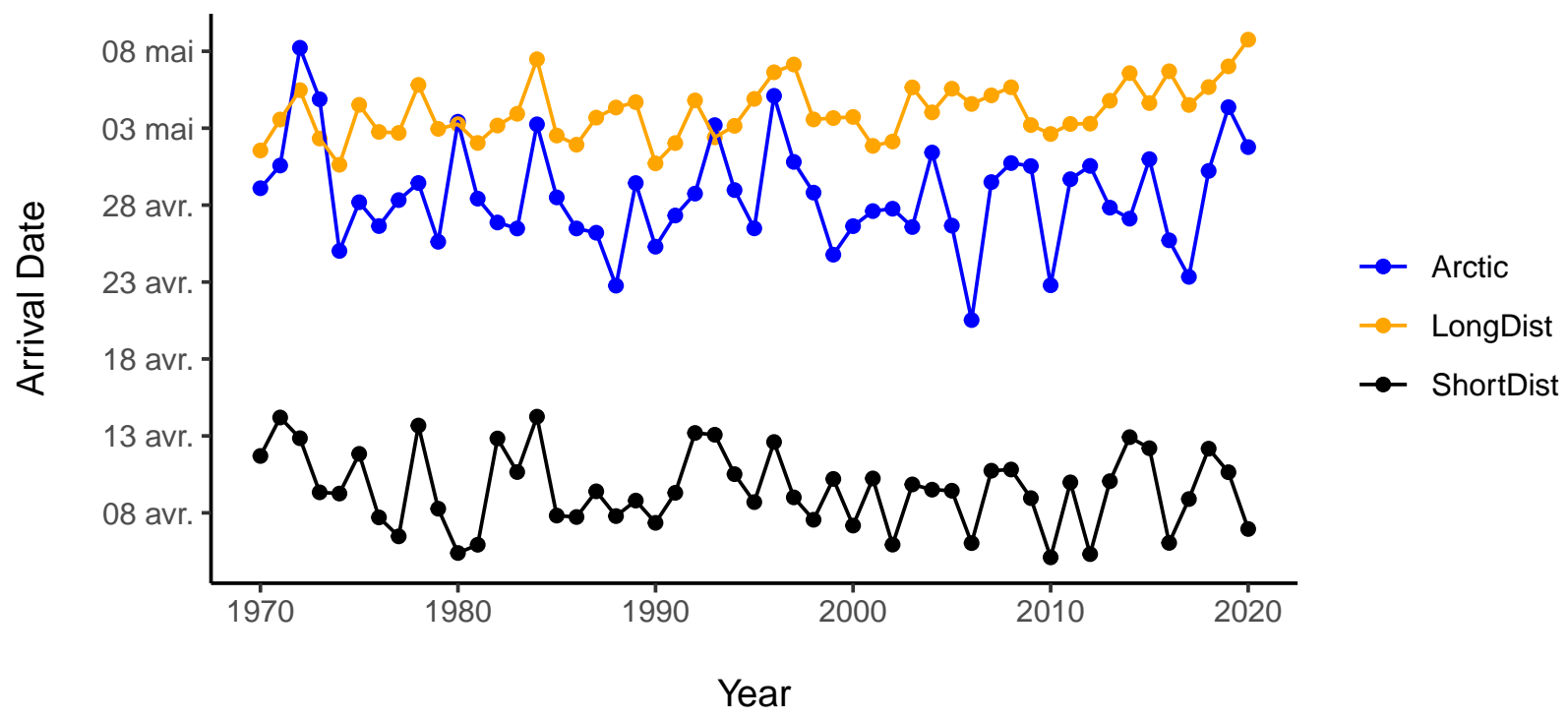

Figure 4: Changes in first arrival dates according to migration distance. Dates were obtained by averaging species-specific first arrival dates over 100 resamples with equal frequency.

some uncommon waterfowl species advanced much faster than their median arrival dates but the reverse happened for some long-distance migrants such as Eastern Wood Pewee (Contopus virens), Common Nighthawk (Chordeiles minor) and Broad-winged Hawk (Buteo platypterus; Fig. 6).

Early arriving species showed greater interannual variation in their migration dates than later arriving species (standard-deviation vs. mean: $r=-0.31, p<0.001, n=149$ ). A similar pattern was found for first arrival dates $(r=-0.27, p<0.001, n=145)$. 
bioRxiv preprint doi: https://doi.org/10.1101/2021.05.25.445655; this version posted May 26, 2021. The copyright holder for this preprint (which

was not certified by peer review) is the author/funder, who has granted bioRxiv a license to display the preprint in perpetuity. It is made available under aCC-BY-NC-ND 4.0 International license.

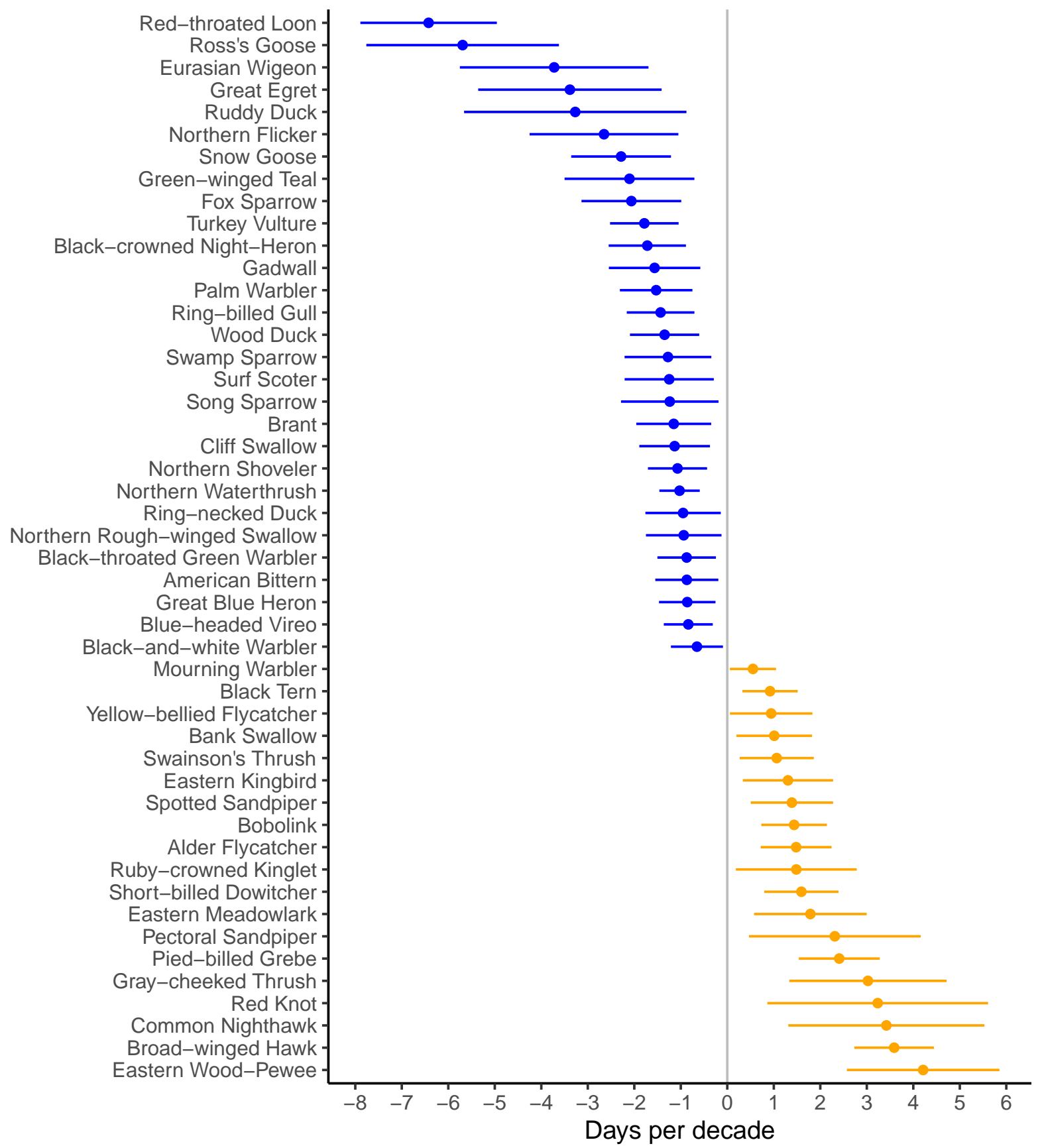

Figure 5: Species with significant 50-year trend in first arrival dates. Bars represent $95 \%$ confidence intervals. 


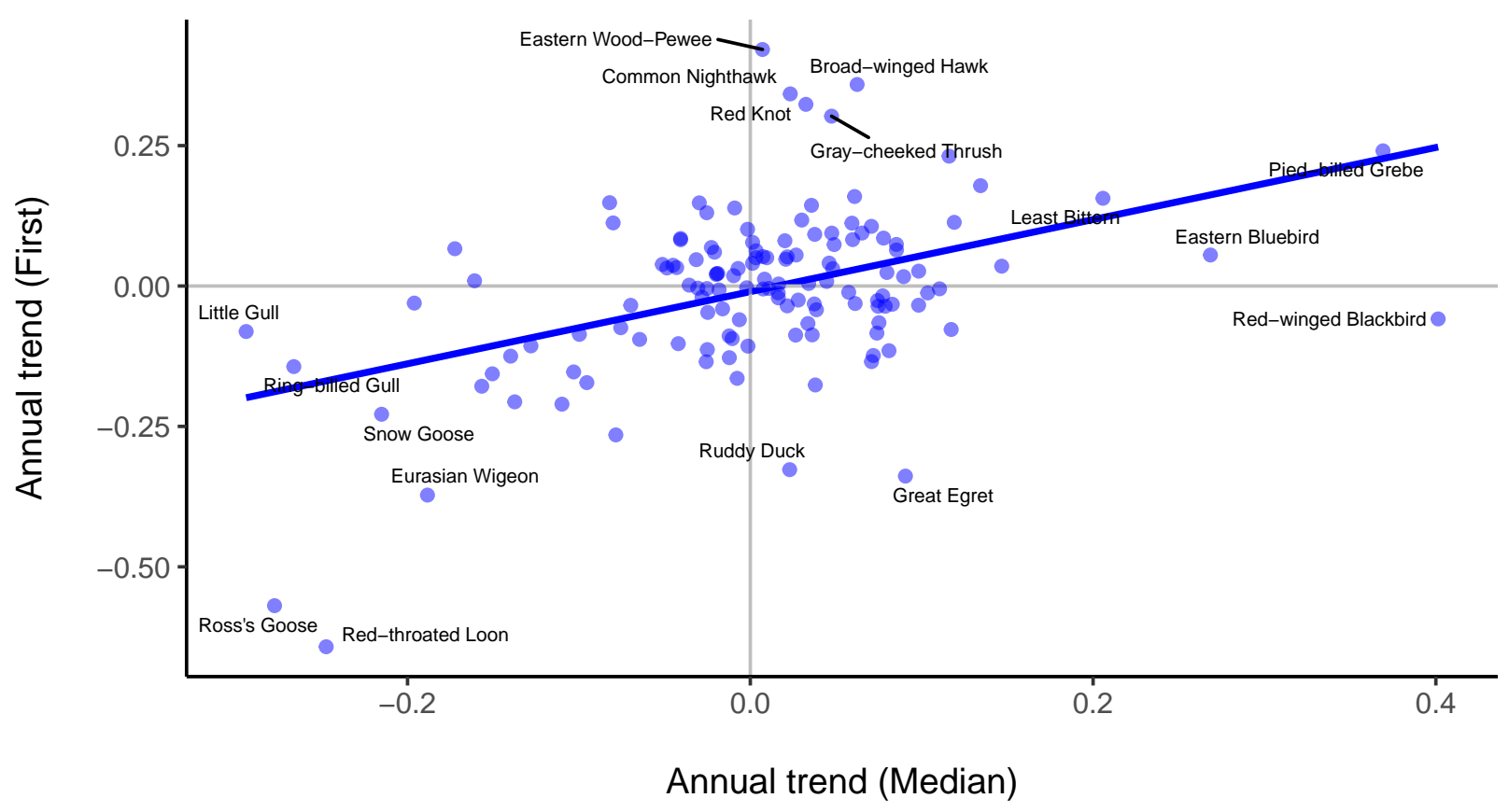

Figure 6: Relationship between 1970-2020 trends in first vs. median arrival dates. Each point represents one species. Outlying species identified only, for clarity.

\section{Discussion}

Shifts in spring migration dates reported in the ornithological literature are the outcome of at least three processes: actual changes in phenology, changes in abundance, and changes in sampling effort. Higher abundances or sampling effort would in most cases lead to earlier dates. Unlike most studies published on the subject, the current study was able to reduce or eliminate potential bias in arrivals due to long-term changes in abundance or sampling effort. In contrast to Horton et al.'s (2020) recent and extensive examination of North American species, we found no consistent change in the spring arrival phenology of birds in northeastern North America. However, we were able to show a great flexibility in migration dates over the last 51 years. A substantial proportion of the species examined shifted their spring arrival dates, one way or another. Among those, several ducks, larids, and arctic-nesting species have advanced their migration by as much as three weeks. By contrast, species that now tend to arrive later included many insectivore neotropical migrants, a group often considered vulnerable to the mismatch between the times of peak food supply and demand during the nestling period (Saino et al., 2011; Both et al., 2009).

\section{The mismeasure of migration}

At first glance, documenting the phenology of spring migration would strike as a simple task, but the literature on the subject shows the opposite. Despite the large variety of data, metrics and modeling methods available, early studies of spring migration phenology often relied on arrival dates. Despite their flaws, first arrival dates have often been used and defended because they were the only available data (e.g. Rubolini et al., 2007) and possibly because of the lack of advanced statistical methods. Knudsen et al. (2007) and Lehikoinen and Sparks (2010) reviewed sampling and analytical problems encountered with the combination of noisy data such as arrival dates, and 
simplistic analytical approaches: truncation, missing data, autocorrelation, nonstationarity, etc. Warnings such as those by Knudsen, Lehikoinen and others are essential to the advancement of the field, but researchers should also consider the tradeoff between transparency and sophistication difficult to comprehend even for statistically-literate readers (e.g. Horton et al., 2020).

Even when sampling bias is dealt with by simple and replicable methods such as those of the present study, limitations remain. For example, our analysis, as many others, estimates the phenology en route or at stopover sites, while most birds observed were presumably en route to their breeding grounds, providing no information on the ultimate arrival dates. Furthermore, in the absence of marked individuals, most studies of temporal changes confound lifetime changes within individuals (especially among long-lived species), and selection among individuals with unchanging migration phenologies. Also, in the case of species breeding in the latitudinal range of the present study, median dates are simply those for which half of the total counts before 10 June were obtained. Thus, the actual meaning of 'median' arrival dates is not independent of the breeding range.

The choice of a time scale adds to the challenge of measuring migration phenology. Lehikoinen warned that "The methodological message provided by long time series is that we should be cautious when short recent time series are used, because of varying directions of 'trends' " (Lehikoinen et al., 2004). Despite shorter-term fluctuations, there is evidence that six common species in Finland have gradually advanced their spring migration since the end of the Little Ice Age (17501988; Fig. 2 in Lehikoinen et al., 2004). Ahas (1999) used "arrival dates" from a 132 year time series from two species (Alauda arvensis, Motacilla alba), and found that trends in arrival dates depended on the timescale used, with an overall trend toward later arrivals by those two species. Ahas (1999) did not define "arrival dates", thus making it impossible to determine possible biases. Mason (1995) reported first arrival dates of 23 species from 1942 to 1991 in England, but did not account for possible effects of a fivefold increase in observer effort over the study period, or a possible abundance bias. Nevertheless, Mason found no overall advance in arrival dates in the 1942-1991 period and speculates that observers 'have always been assiduous in noting [bird arrivals]'. Unfortunately, an absence of change in 'assiduity' does not remove the bias due to changing numbers of observers or birds observed.

\section{A Nearctic perspective}

How similar are trends in spring migration in eastern North America relative to Europe and Asia? Based on available literature at the time, Knudsen et al. (2011) concluded that changes in migration phenology were similar between Palearctic and Nearctic birds. However, North American studies published so far were of relatively short duration, possibly leading to unreliable estimates. Hurlbert et al. (2012) argued that in the United States, southeastern species advanced their migration dates more than northern counterparts, over the period 2000-2010. But more recently, Horton et al. (2020) concluded from weather radar data that birds in the United States substantially advanced migration dates from 1995 to 2018, especially in the north of the country. Horton et al.'s findings are consistent with other studies suggesting that advancement of spring migration has been stronger in boreal latitudes than in more southerly latitudes (Rubolini et al., 2007; Horton et al., 2020; Post et al., 2018; but see Parmesan, 2007). If estimates from Horton et al. (2020) as well as Palearctic studies (Lehikoinen et al., 2004; Rubolini et al., 2007) are to be trusted, we would expect a general advance of spring migration by one to three weeks over the last 51 years. Those estimates are inconsistent with what Quebec birders have experienced and reported in the same period, as shown in the present study.

An earlier, unpublished, study based on ÉPOQ concluded that the spring migration of 113 
species advanced in Quebec over the period 1969-2008, by 1.3 day per decade (Francoeur, 2012), a figure consistent with the 1.0 day per decade obtained by Lehikoinen et al. (2004). However, this conclusion was based on one of nine metrics used, the 25th percentile arrival date. We question this choice of metric, given that two of the metrics available were unbiased (first arrival and median dates based on random, equal-sized samples) and yielded much subtler trends in migration dates. Constrasting results among studies on north American birds migration phenology raises questions about this general advancement pattern being a 'flagship example of the biological impacts of climate change' as claimed by many, like Kelly et al. (2017).

\section{Searching for mechanisms}

Widely cited studies describing phenological changes in taxa (e.g., Root et al., 2005; Parmesan, 2007) usually come with numerous caveats, but they are often cited to support claims that changes in phenology are common, unidirectional, and essentially caused by a changing climate (e.g., Kelly et al., 2017; Miller-Rushing et al., 2008; Newson et al., 2016; Settele et al., 2014). But several authors argue that we need a more 'mechanistic' approach to the study of migration phenology to enable attribution to climate change (Knudsen et al., 2011; Chmura et al., 2019; Thackeray et al., 2016). Without a mechanistic understanding, projections into the future will be unreliable, if not misleading. To materialize their pledge for a more 'mechanistic' approach, Thackeray et al. (2016) analysed 10,003 terrestrial and aquatic phenological data sets from 812 taxa, and concluded that the phenology of species at the "primary consumer" trophic level is more sensitive to climate change than that of other species.

Our theoretical understanding, and thus our expectations, about the phenotypical responses of birds to a warming climate thus remains superficial, and would benefit from more specific predictions, such as those that could emerge from regional comparisons in phenological responses. For example, if the rate of climate warming has an effect on migration phenology, we should expect a weaker phenological trend in eastern North America than what has been found in the Palearctic, because warming has been slower in eastern North America than in other regions where most of the studies on migration phenology have occurred (Fig.1 in Hansen et al. (2006)). Furthermore, arctic-nesting species should advance their migration dates more than other species, because in recent decades, global warming has been mostly concentrated in higher latitudes (IPCC, 2013). Our results concerning migration distances are consistent with the latter two predictions, as well as the findings of several other studies (Lehikoinen and Sparks, 2010), but exceptions remain (Jonzén et al., 2006; Sullivan et al., 2016).

One way by which the present study may advance our understanding of mechanisms leading to phenological changes is finding that species associated to open water, which should respond strongly to ice cover advanced their migration dates more than most other species. Butler (2003) also observed that aquatic species were among the most responsive species. Coincidentally since 1970, ice cover in early spring has retreated, from the Great Lakes to the Gulf of the St. Lawrence (Fig. 7). Further study of year-to-year variations in ice cover and other regional phenomena such as the North Atlantic Oscillation (Stenseth et al., 2003; Haest et al., 2018) and their correlation with spring arrival dates would help evaluate causal factors. A spatially-explicit examination of eBird data such as those used in the present study, and short-term weather fluctuations may provide answers, but this is outside the scope of the current study.

We expect short-distance migrants to be influenced mostly by regional cues, in contrast to long-distance migrants that are driven mostly by photoperiodic and endogenous cues (Chmura et al., 2019). In several papers (e.g., Both and Visser, 2001), Both and coworkers portrayed arrival dates as relatively inflexible, especially in long-distance migrants, due to the lack of relevant cues 


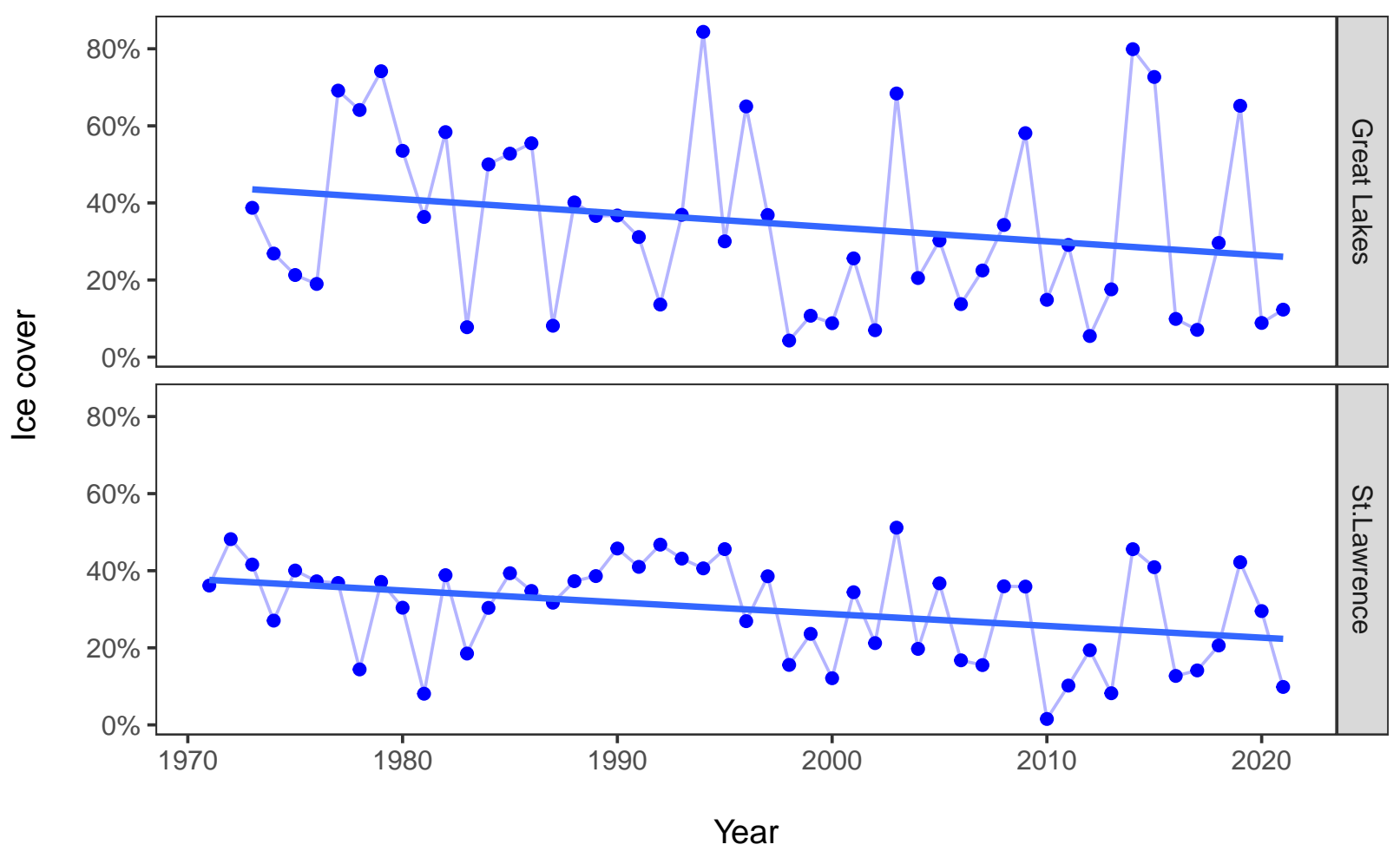

Figure 7: Decreasing total ice cover of the St. Lawrence river system, from the Great Lakes to the Gulf, on the first week of March. Trends were significant $(p=0.009)$ and similar between regions $(p=0.16)$. Data from Environment anc Climate Change Canada (https://iceweb1.cis.ec.gc.ca/ IceGraph/) 
in the wintering grounds and the apparent reliance on photoperiod (Gwinner and Helm, 2003).

Some authors argue that early migrating species are more variable in their arrival dates than later-arriving species, as was the case here, because of greater variability in early spring weather (Sparks et al., 2001). If regional weather is used as a cue by short-distance migrants, authors have hypothesized that changes in migration phenology should be greatest in short-distance migrants. However, in their review, Knudsen et al. (2011) concluded that evidence for differential trends in spring migration phenology according to migration distance was mixed. The evidence from the present study adds another layer of mixed evidence: long-distance migrants did not advance their first arrival dates as much as short-distance migrants or arctic-nesting species, but we found no significant difference among species groups when median arrival dates were used.

\section{Concerns about phenology}

With the accumulating evidence on changes in the phenology of plants and insects in temperate and northern regions, concerns have been raised about a possible mismatch between dates of maximal food availability and dates of maximal nestling growth (Saino et al., 2011; Both et al., 2009), and its consequences on populations. Fueling this concern, Møller concluded that populations of migratory bird species that did not show a phenological response to climate change are declining (Møller et al., 2008). Visser and Both (2005) went further and argued that desynchronization may lead to 'severe ecological dysfunction'. Those concerns are based on the possibility that arrival dates are generally not flexible enough (Both and Visser, 2001), which appears counter to the available evidence (Knudsen et al., 2011), including our own study. It remains possible that changes in migration dates are outpaced by phenological changes in breeding ranges, as has been documented in Europe (Saino et al., 2011), but the population consequences of ecological mismatches between arrival dates and optimal conditions for nesting remain little understood (Knudsen et al., 2011).

If ecological mismatch were to lead to 'ecological dysfunction' (Visser and Both, 2005), one would expect measurable evolutionary responses, given that factors triggering the onset of migration have a strong genetic basis (Berthold et al., 2003). Phenotypic plasticity, the facultative change in behavior or physiology induced by environmental change, is often assumed to trump Darwinian evolution as a mechanism of change in migration phenology (Van Buskirk et al., 2012; Gordo, 2007). Phenotypic plasticity of the timing of migration has been demonstrated (Saino et al., 2004; Gienapp et al., 2007), but longitudinal studies using artificial selection (Pulido et al., 2001) and passive studies based on marked individuals (Gill et al., 2014; Adriaensen et al., 1993; Møller, 2004; Brown and Brown, 2000) suggest that rapid evolution also takes place. To date, the relative roles of phenotypic vs. evolutionary responses remain poorly understood (Knudsen et al., 2011; Pulido and Berthold, 2004; Berteaux et al., 2004), with indirect evidence for changes in allele frequencies responses to changing spring climate (Jonzén et al., 2006). However, other studies came to different conclusions (Both, 2007; Jonzén et al., 2007; Gill et al., 2014). Some researchers believe that rapid evolution may not be sufficient to compensate for shifting climate patterns (Lehikoinen and Sparks, 2010; Radchuk et al., 2019). Others (Both and te Marvelde, 2007) acknowledge that evolutionary pressures for an optimal match between arrival dates and the production of food will modify departure rules based on photoperiod and may therefore answer concerns about negative impacts of changes in ecosystem vs. migration phenology. 


\section{Conclusion}

Several authors claim that the advance in spring migration is among the best documented biological responses to climate change (e.g. Miller-Rushing et al., 2008), but our study and several others question this perception. Phenological responses by migrating birds are too diverse to be the result of a simple, overarching, phenomenon. Furthermore, even if a substantial number of species have shown their ability to shift their migration phenology, many of them have not. Those birds may not experience enough pressure to change, or they may be incapable to respond swiftly to changes in climate or other phenomena occurring in spring (Both and Visser, 2001). Determining whether temporal changes in phenology, or the lack thereof, are adaptive will continue to challenge our understanding of causes and consequences of migration phenology, especially while our understanding of the patterns themselves remains unsettled.

\section{Acknowledgements}

Thanks to Marshall Illiff and Jenna Curtis at eBird for the support with data management. Thanks to Dominique Berteaux, Jacques Larivée, Jean-Pierre Savard, and Pascal Côté for thoughtful comments on an earlier draft of this paper. 


\section{Appendix}

Table 1: List of species, sorted by taxonomic order, within migration distance group. Records denote the number of checklist reporting the species. Latitudes are means, weighted by number of records. Means and standard errors of trend estimates (days per decade) are shown for first and median arrival dates. First arrival trends were not calculated for species with lowest annual numbers of records $<10$.

\begin{tabular}{|c|c|c|c|c|c|}
\hline English & Scientific & Records & Winter Lat & First & Median \\
\hline \multicolumn{6}{|l|}{ Arctic Nesters } \\
\hline Snow Goose & Anser caerulescens & 44068 & $39^{\circ}$ & $-2.28 \pm 0.55$ & $-2.15 \pm 0.61$ \\
\hline Ross's Goose & Anser rossii & 1108 & $34^{\circ}$ & $-5.69 \pm 1.06$ & $-2.78 \pm 0.9$ \\
\hline Brant & Branta bernicla & 14693 & $40^{\circ}$ & $-1.15 \pm 0.41$ & $0.81 \pm 0.73$ \\
\hline Black-bellied Plover & Pluvialis squatarola & 3658 & $28^{\circ}$ & $0.32 \pm 0.6$ & $-0.49 \pm 0.32$ \\
\hline American Golden-Plover & Pluvialis dominica & 266 & $-35^{\circ}$ & & $1.57 \pm 1.33$ \\
\hline Semipalmated Plover & Charadrius semipalmatus & 6585 & $30^{\circ}$ & $0.82 \pm 0.43$ & $-0.41 \pm 0.25$ \\
\hline Whimbrel & Numenius phaeopus & 90 & $-34^{\circ}$ & & $4.11 \pm 1.71$ \\
\hline Hudsonian Godwit & Limosa haemastica & 137 & $-43^{\circ}$ & & $0.26 \pm 0.98$ \\
\hline Ruddy Turnstone & Arenaria interpres & 1355 & $28^{\circ}$ & $0.21 \pm 0.61$ & $-0.2 \pm 0.25$ \\
\hline Red Knot & Calidris canutus & 476 & $26^{\circ}$ & $3.23 \pm 1.21$ & $0.32 \pm 0.63$ \\
\hline Stilt Sandpiper & Calidris himantopus & 75 & $18^{\circ}$ & & $1.74 \pm 1.95$ \\
\hline Sanderling & Calidris alba & 323 & $28^{\circ}$ & & $0.01 \pm 0.68$ \\
\hline Dunlin & Calidris alpina & 3386 & $31^{\circ}$ & $-0.89 \pm 0.8$ & $-0.12 \pm 0.43$ \\
\hline Baird's Sandpiper & Calidris bairdii & 27 & $-31^{\circ}$ & & $-1.32 \pm 1.02$ \\
\hline Least Sandpiper & Calidris minutilla & 10472 & $28^{\circ}$ & $0.33 \pm 0.48$ & $-0.43 \pm 0.24$ \\
\hline White-rumped Sandpiper & Calidris fuscicollis & 920 & $-52^{\circ}$ & $0.48 \pm 0.79$ & $0.21 \pm 0.53$ \\
\hline Pectoral Sandpiper & Calidris melanotos & 819 & $-31^{\circ}$ & $2.31 \pm 0.94$ & $1.16 \pm 1.03$ \\
\hline Semipalmated Sandpiper & Calidris pusilla & 3482 & $4^{\circ}$ & $-0.74 \pm 0.37$ & $-0.76 \pm 0.31$ \\
\hline Red-necked Phalarope & Phalaropus lobatus & 384 & $-1^{\circ}$ & & $0.72 \pm 0.58$ \\
\hline Parasitic Jaeger & Stercorarius parasiticus & 555 & $27^{\circ}$ & & $-0.83 \pm 0.73$ \\
\hline Red-throated Loon & Gavia stellata & 2809 & $36^{\circ}$ & $-6.42 \pm 0.75$ & $-2.47 \pm 0.58$ \\
\hline American Pipit & Anthus rubescens & 5640 & $31^{\circ}$ & $1.12 \pm 0.73$ & $0.59 \pm 0.4$ \\
\hline \multicolumn{6}{|l|}{ Long-Distance Migrants } \\
\hline Blue-winged Teal & Spatula discors & 17833 & $19^{\circ}$ & $0.12 \pm 0.39$ & $0.08 \pm 0.34$ \\
\hline Black-billed Cuckoo & Coccyzus erythropthalmus & 2059 & $-3^{\circ}$ & $1.17 \pm 0.63$ & $0.3 \pm 0.44$ \\
\hline Common Nighthawk & Chordeiles minor & 2791 & $-2^{\circ}$ & $3.42 \pm 1.08$ & $0.23 \pm 0.26$ \\
\hline Eastern Whip-poor-will & Antrostomus vociferus & 1542 & $27^{\circ}$ & $0.74 \pm 0.7$ & $0.49 \pm 0.44$ \\
\hline Chimney Swift & Chaetura pelagica & 15579 & $8^{\circ}$ & $0.26 \pm 0.42$ & $0.98 \pm 0.36$ \\
\hline Ruby-throated Hummingbird & Archilochus colubris & 33475 & $25^{\circ}$ & $-0.47 \pm 0.34$ & $-0.25 \pm 0.2$ \\
\hline Upland Sandpiper & Bartramia longicauda & 2166 & $-32^{\circ}$ & $-0.2 \pm 0.44$ & $-0.28 \pm 0.51$ \\
\hline Wilson's Phalarope & Phalaropus tricolor & 1168 & $-31^{\circ}$ & $0.66 \pm 0.67$ & $-1.72 \pm 0.64$ \\
\hline Spotted Sandpiper & Actitis macularius & 34531 & $15^{\circ}$ & $1.39 \pm 0.45$ & $-0.09 \pm 0.19$ \\
\hline Solitary Sandpiper & Tringa solitaria & 9960 & $10^{\circ}$ & $0.22 \pm 0.41$ & $-0.2 \pm 0.23$ \\
\hline Lesser Yellowlegs & Tringa flavipes & 10043 & $25^{\circ}$ & $0.38 \pm 0.38$ & $-0.51 \pm 0.38$ \\
\hline Caspian Tern & Hydroprogne caspia & 624 & $27^{\circ}$ & $-1.76 \pm 1.47$ & $0.38 \pm 1.21$ \\
\hline Black Tern & Chlidonias niger & 4667 & $9^{\circ}$ & $0.92 \pm 0.3$ & $0.38 \pm 0.34$ \\
\hline Common Tern & Sterna hirundo & 12238 & $-36^{\circ}$ & $0.74 \pm 0.46$ & $0.85 \pm 0.5$ \\
\hline Arctic Tern & Sterna paradisaea & 632 & $-65^{\circ}$ & & $0.56 \pm 0.53$ \\
\hline Least Bittern & Ixobrychus exilis & 1247 & $25^{\circ}$ & $1.56 \pm 2.93$ & $2.06 \pm 0.61$ \\
\hline Green Heron & Butorides virescens & 6264 & $22^{\circ}$ & $0.04 \pm 0.46$ & $0.34 \pm 0.28$ \\
\hline Osprey & Pandion haliaetus & 27592 & $27^{\circ}$ & $-0.6 \pm 0.39$ & $-0.06 \pm 0.32$ \\
\hline Broad-winged Hawk & Buteo platypterus & 18993 & $10^{\circ}$ & $3.59 \pm 0.44$ & $0.62 \pm 0.54$ \\
\hline Olive-sided Flycatcher & Contopus cooperi & 2881 & $5^{\circ}$ & $0.69 \pm 0.39$ & $-0.23 \pm 0.24$ \\
\hline Eastern Wood-Pewee & Contopus virens & 13199 & $-1^{\circ}$ & $4.21 \pm 0.84$ & $0.07 \pm 0.22$ \\
\hline
\end{tabular}


bioRxiv preprint doi: https://doi.org/10.1101/2021.05.25.445655; this version posted May 26, 2021. The copyright holder for this preprint (which was not certified by peer review) is the author/funder, who has granted bioRxiv a license to display the preprint in perpetuity. It is made available under aCC-BY-NC-ND 4.0 International license.

Table 1: (continued)

\begin{tabular}{|c|c|c|c|c|c|}
\hline English & Scientific & Records & Winter Lat & First & Median \\
\hline Yellow-bellied Flycatcher & Empidonax flaviventris & 4450 & $14^{\circ}$ & $0.94 \pm 0.45$ & $0.65 \pm 0.28$ \\
\hline Alder Flycatcher & Empidonax alnorum & 20841 & $-7^{\circ}$ & $1.48 \pm 0.39$ & $-0.3 \pm 0.18$ \\
\hline Willow Flycatcher & Empidonax traillii & 2727 & $13^{\circ}$ & $-0.25 \pm 0.84$ & $0.28 \pm 0.37$ \\
\hline Least Flycatcher & Empidonax minimus & 34663 & $17^{\circ}$ & $0.18 \pm 0.43$ & $-0.1 \pm 0.2$ \\
\hline Great Crested Flycatcher & Myiarchus crinitus & 25569 & $24^{\circ}$ & $0.81 \pm 0.53$ & $0.2 \pm 0.2$ \\
\hline Eastern Kingbird & Tyrannus tyrannus & 29720 & $-18^{\circ}$ & $1.3 \pm 0.5$ & $-0.25 \pm 0.2$ \\
\hline Philadelphia Vireo & Vireo philadelphicus & 10013 & $10^{\circ}$ & $-0.18 \pm 0.26$ & $0.77 \pm 0.22$ \\
\hline Warbling Vireo & Vireo gilvus & 30305 & $16^{\circ}$ & $-0.42 \pm 0.34$ & $0.39 \pm 0.27$ \\
\hline Red-eyed Vireo & Vireo olivaceus & 42105 & $4^{\circ}$ & $0.4 \pm 0.33$ & $0.01 \pm 0.2$ \\
\hline Northern Rough-winged Swallow & Stelgidopteryx serripennis & 4896 & $25^{\circ}$ & $-0.94 \pm 0.41$ & $-0.11 \pm 0.55$ \\
\hline Tree Swallow & Tachycineta bicolor & 124024 & $27^{\circ}$ & $0.31 \pm 0.45$ & $0.48 \pm 0.39$ \\
\hline Bank Swallow & Riparia riparia & 15265 & $-4^{\circ}$ & $1.01 \pm 0.41$ & $-0.02 \pm 0.31$ \\
\hline Barn Swallow & Hirundo rustica & 43331 & $9^{\circ}$ & $-0.05 \pm 0.48$ & $-0.25 \pm 0.25$ \\
\hline Cliff Swallow & Petrochelidon pyrrhonota & 13273 & $-34^{\circ}$ & $-1.13 \pm 0.39$ & $-0.25 \pm 0.38$ \\
\hline House Wren & Troglodytes aedon & 15429 & $18^{\circ}$ & $0.02 \pm 0.48$ & $-0.36 \pm 0.35$ \\
\hline Gray Catbird & Dumetella carolinensis & 34887 & $27^{\circ}$ & $0.85 \pm 0.82$ & $-0.41 \pm 0.18$ \\
\hline Veery & Catharus fuscescens & 40679 & $1^{\circ}$ & $0.83 \pm 0.53$ & $0.6 \pm 0.18$ \\
\hline Gray-cheeked Thrush & Catharus minimus & 1009 & $5^{\circ}$ & $3.02 \pm 0.86$ & $0.47 \pm 0.42$ \\
\hline Swainson's Thrush & Catharus ustulatus & 18549 & $4^{\circ}$ & $1.06 \pm 0.41$ & $0.71 \pm 0.31$ \\
\hline Wood Thrush & Hylocichla mustelina & 10200 & $16^{\circ}$ & $0.52 \pm 0.4$ & $0.07 \pm 0.2$ \\
\hline Bobolink & Dolichonyx oryzivorus & 22641 & $-27^{\circ}$ & $1.44 \pm 0.36$ & $0.36 \pm 0.18$ \\
\hline Baltimore Oriole & Icterus galbula & 35268 & $16^{\circ}$ & $0.04 \pm 0.34$ & $0.17 \pm 0.19$ \\
\hline Ovenbird & Seiurus aurocapilla & 44731 & $21^{\circ}$ & $-0.32 \pm 0.31$ & $0.37 \pm 0.17$ \\
\hline Northern Waterthrush & Parkesia noveboracensis & 22072 & $17^{\circ}$ & $-1.03 \pm 0.22$ & $-0.42 \pm 0.23$ \\
\hline Black-and-white Warbler & Mniotilta varia & 34769 & $20^{\circ}$ & $-0.65 \pm 0.29$ & $0.75 \pm 0.14$ \\
\hline Tennessee Warbler & Leiothlypis peregrina & 20620 & $10^{\circ}$ & $0.41 \pm 0.31$ & $0.46 \pm 0.31$ \\
\hline Nashville Warbler & Leiothlypis ruficapilla & 34591 & $18^{\circ}$ & $-0.12 \pm 0.28$ & $1.03 \pm 0.21$ \\
\hline Mourning Warbler & Geothlypis philadelphia & 8708 & $8^{\circ}$ & $0.55 \pm 0.25$ & $0.27 \pm 0.21$ \\
\hline American Redstart & Setophaga ruticilla & 49227 & $18^{\circ}$ & $0.5 \pm 0.35$ & $0.1 \pm 0.16$ \\
\hline Cape May Warbler & Setophaga tigrina & 14925 & $21^{\circ}$ & $0.24 \pm 0.26$ & $0.8 \pm 0.23$ \\
\hline Northern Parula & Setophaga americana & 20793 & $24^{\circ}$ & $-0.32 \pm 0.26$ & $0.83 \pm 0.23$ \\
\hline Magnolia Warbler & Setophaga magnolia & 33587 & $17^{\circ}$ & $0.08 \pm 0.27$ & $0.45 \pm 0.25$ \\
\hline Bay-breasted Warbler & Setophaga castanea & 11951 & $8^{\circ}$ & $-0.07 \pm 0.26$ & $-0.18 \pm 0.31$ \\
\hline Blackburnian Warbler & Setophaga fusca & 19105 & $4^{\circ}$ & $-0.11 \pm 0.29$ & $0.57 \pm 0.22$ \\
\hline Yellow Warbler & Setophaga petechia & 61288 & $13^{\circ}$ & $0.52 \pm 0.45$ & $0.22 \pm 0.19$ \\
\hline Chestnut-sided Warbler & Setophaga pensylvanica & 35007 & $9^{\circ}$ & $-0.04 \pm 0.29$ & $0.11 \pm 0.22$ \\
\hline Blackpoll Warbler & Setophaga striata & 13559 & $3^{\circ}$ & $-0.04 \pm 0.27$ & $-0.31 \pm 0.22$ \\
\hline Black-throated Blue Warbler & Setophaga caerulescens & 26497 & $19^{\circ}$ & $-0.26 \pm 0.31$ & $0.74 \pm 0.16$ \\
\hline Black-throated Green Warbler & Setophaga virens & 35446 & $16^{\circ}$ & $-0.87 \pm 0.32$ & $0.26 \pm 0.18$ \\
\hline Canada Warbler & Cardellina canadensis & 10321 & $3^{\circ}$ & $-0.03 \pm 0.2$ & $-0.02 \pm 0.17$ \\
\hline Wilson's Warbler & Cardellina pusilla & 10764 & $16^{\circ}$ & $0.31 \pm 0.37$ & $-0.07 \pm 0.24$ \\
\hline Scarlet Tanager & Piranga olivacea & 9331 & $-1^{\circ}$ & $-0.21 \pm 0.31$ & $0.16 \pm 0.21$ \\
\hline Rose-breasted Grosbeak & Pheucticus ludovicianus & 36865 & $14^{\circ}$ & $0.22 \pm 0.76$ & $-0.19 \pm 0.16$ \\
\hline Indigo Bunting & Passerina cyanea & 8174 & $20^{\circ}$ & $-0.12 \pm 0.67$ & $0.16 \pm 0.27$ \\
\hline \multicolumn{6}{|l|}{ Short-Distance Migrants } \\
\hline Wood Duck & Aix sponsa & 39069 & $33^{\circ}$ & $-1.35 \pm 0.38$ & $-0.26 \pm 0.56$ \\
\hline Northern Shoveler & Spatula clypeata & 25242 & $31^{\circ}$ & $-1.07 \pm 0.32$ & $-0.01 \pm 0.43$ \\
\hline Gadwall & Mareca strepera & 24968 & $35^{\circ}$ & $-1.56 \pm 0.5$ & $-1.51 \pm 0.76$ \\
\hline Eurasian Wigeon & Mareca penelope & 1468 & $41^{\circ}$ & $-3.72 \pm 1.03$ & $-1.88 \pm 0.91$ \\
\hline American Wigeon & Mareca americana & 33949 & $34^{\circ}$ & $-1.07 \pm 0.57$ & $-1.28 \pm 0.39$ \\
\hline Green-winged Teal & Anas crecca & 41664 & $32^{\circ}$ & $-2.1 \pm 0.71$ & $-1.1 \pm 0.32$ \\
\hline Redhead & Aythya americana & 6472 & $41^{\circ}$ & $1.13 \pm 0.75$ & $1.19 \pm 1.11$ \\
\hline Ring-necked Duck & Aythya collaris & 46733 & $35^{\circ}$ & $-0.95 \pm 0.41$ & $-0.65 \pm 0.32$ \\
\hline Surf Scoter & Melanitta perspicillata & 10555 & $40^{\circ}$ & $-1.25 \pm 0.49$ & $-1.4 \pm 0.59$ \\
\hline
\end{tabular}

(Continued on Next Page...) 
bioRxiv preprint doi: https://doi.org/10.1101/2021.05.25.445655; this version posted May 26, 2021. The copyright holder for this preprint (which was not certified by peer review) is the author/funder, who has granted bioRxiv a license to display the preprint in perpetuity. It is made available under aCC-BY-NC-ND 4.0 International license.

Table 1: (continued)

\begin{tabular}{|c|c|c|c|c|c|}
\hline English & Scientific & Records & Winter Lat & First & Median \\
\hline Ruddy Duck & Oxyura jamaicensis & 2184 & $36^{\circ}$ & $-3.27 \pm 1.22$ & $0.23 \pm 1.28$ \\
\hline Pied-billed Grebe & Podilymbus podiceps & 22372 & $31^{\circ}$ & $2.41 \pm 0.44$ & $3.69 \pm 0.51$ \\
\hline Virginia Rail & Rallus limicola & 6801 & $31^{\circ}$ & $-0.35 \pm 0.7$ & $0.22 \pm 0.48$ \\
\hline Sora & Porzana carolina & 6860 & $28^{\circ}$ & $-0.36 \pm 0.47$ & $0.75 \pm 0.34$ \\
\hline Common Gallinule & Gallinula galeata & 6538 & $28^{\circ}$ & $-0.31 \pm 0.26$ & $0.61 \pm 0.37$ \\
\hline American Coot & Fulica americana & 3958 & $29^{\circ}$ & $-0.36 \pm 0.81$ & $0.79 \pm 0.88$ \\
\hline Sandhill Crane & Antigone canadensis & 6355 & $36^{\circ}$ & & $1.63 \pm 1.37$ \\
\hline Piping Plover & Charadrius melodus & 319 & $28^{\circ}$ & & $-2.66 \pm 1.01$ \\
\hline Killdeer & Charadrius vociferus & 84594 & $30^{\circ}$ & $0.35 \pm 0.5$ & $1.47 \pm 0.26$ \\
\hline Short-billed Dowitcher & Limnodromus griseus & 3364 & $28^{\circ}$ & $1.59 \pm 0.41$ & $0.61 \pm 0.28$ \\
\hline American Woodcock & Scolopax minor & 13318 & $37^{\circ}$ & $0.47 \pm 0.48$ & $-0.32 \pm 0.56$ \\
\hline Wilson's Snipe & Gallinago delicata & 33379 & $31^{\circ}$ & $0.64 \pm 0.84$ & $0.85 \pm 0.32$ \\
\hline Greater Yellowlegs & Tringa melanoleuca & 19935 & $28^{\circ}$ & $0.09 \pm 0.52$ & $-1.61 \pm 0.28$ \\
\hline Razorbill & Alca torda & 2870 & $41^{\circ}$ & & $0.97 \pm 1.34$ \\
\hline Bonaparte's Gull & Chroicocephalus philadelphia & 6762 & $37^{\circ}$ & $0.37 \pm 0.66$ & $-0.45 \pm 0.7$ \\
\hline Little Gull & Hydrocoloeus minutus & 391 & $40^{\circ}$ & $-0.81 \pm 0.77$ & $-2.94 \pm 1.06$ \\
\hline Ring-billed Gull & Larus delawarensis & 175291 & $38^{\circ}$ & $-1.43 \pm 0.37$ & $-2.66 \pm 0.97$ \\
\hline Northern Gannet & Morus bassanus & 7027 & $36^{\circ}$ & & $2.55 \pm 1.45$ \\
\hline Double-crested Cormorant & Phalacrocorax auritus & 51237 & $33^{\circ}$ & $-0.3 \pm 0.3$ & $-1.96 \pm 0.6$ \\
\hline American Bittern & Botaurus lentiginosus & 17414 & $28^{\circ}$ & $-0.87 \pm 0.35$ & $0.36 \pm 0.28$ \\
\hline Great Blue Heron & Ardea herodias & 70534 & $32^{\circ}$ & $-0.86 \pm 0.31$ & $-1 \pm 0.5$ \\
\hline Great Egret & Ardea alba & 6452 & $28^{\circ}$ & $-3.38 \pm 1.01$ & $0.91 \pm 1.23$ \\
\hline Black-crowned Night-Heron & Nycticorax nycticorax & 12152 & $29^{\circ}$ & $-1.72 \pm 0.42$ & $-0.95 \pm 0.7$ \\
\hline Turkey Vulture & Cathartes aura & 66554 & $28^{\circ}$ & $-1.78 \pm 0.38$ & $-1.57 \pm 0.64$ \\
\hline Northern Harrier & Circus hudsonius & 45314 & $36^{\circ}$ & $-0.34 \pm 0.49$ & $-0.7 \pm 0.3$ \\
\hline Belted Kingfisher & Megaceryle alcyon & 47392 & $32^{\circ}$ & $0.6 \pm 0.69$ & $-0.21 \pm 0.18$ \\
\hline Yellow-bellied Sapsucker & Sphyrapicus varius & 51095 & $33^{\circ}$ & $0.85 \pm 0.59$ & $0.78 \pm 0.43$ \\
\hline Northern Flicker & Colaptes auratus & 118956 & $37^{\circ}$ & $-2.65 \pm 0.82$ & $-0.78 \pm 0.22$ \\
\hline Eastern Phoebe & Sayornis phoebe & 47743 & $30^{\circ}$ & $0.5 \pm 0.45$ & $0.03 \pm 0.36$ \\
\hline Blue-headed Vireo & Vireo solitarius & 24176 & $29^{\circ}$ & $-0.84 \pm 0.27$ & $0.74 \pm 0.24$ \\
\hline Purple Martin & Progne subis & 6139 & $28^{\circ}$ & $0.63 \pm 0.42$ & $0.03 \pm 0.46$ \\
\hline Ruby-crowned Kinglet & Regulus calendula & 72092 & $30^{\circ}$ & $1.48 \pm 0.66$ & $-0.82 \pm 0.32$ \\
\hline Winter Wren & Troglodytes hiemalis & 33425 & $36^{\circ}$ & $-1.35 \pm 0.72$ & $0.71 \pm 0.23$ \\
\hline Marsh Wren & Cistothorus palustris & 4775 & $29^{\circ}$ & $-0.41 \pm 0.6$ & $-0.16 \pm 0.45$ \\
\hline Brown Thrasher & Toxostoma rufum & 18604 & $33^{\circ}$ & $-1.64 \pm 1$ & $-0.08 \pm 0.29$ \\
\hline Eastern Bluebird & Sialia sialis & 14520 & $36^{\circ}$ & $0.55 \pm 0.56$ & $2.68 \pm 0.81$ \\
\hline Hermit Thrush & Catharus guttatus & 41443 & $34^{\circ}$ & $-0.77 \pm 0.44$ & $1.17 \pm 0.34$ \\
\hline Chipping Sparrow & Spizella passerina & 104345 & $31^{\circ}$ & $1.12 \pm 0.78$ & $-0.8 \pm 0.16$ \\
\hline Fox Sparrow & Passerella iliaca & 19614 & $37^{\circ}$ & $-2.06 \pm 0.55$ & $-1.37 \pm 0.57$ \\
\hline Vesper Sparrow & Pooecetes gramineus & 5418 & $30^{\circ}$ & $-0.05 \pm 0.49$ & $1.1 \pm 0.55$ \\
\hline LeConte's Sparrow & Ammospiza leconteii & 310 & $31^{\circ}$ & & $1.38 \pm 0.91$ \\
\hline Nelson's Sparrow & Ammospiza nelsoni & 296 & $29^{\circ}$ & & $1.7 \pm 0.7$ \\
\hline Savannah Sparrow & Passerculus sandwichensis & 46146 & $30^{\circ}$ & $0.94 \pm 0.65$ & $0.48 \pm 0.22$ \\
\hline Song Sparrow & Melospiza melodia & 237549 & $37^{\circ}$ & $-1.24 \pm 0.53$ & $0.72 \pm 0.24$ \\
\hline Lincoln's Sparrow & Melospiza lincolnii & 9846 & $29^{\circ}$ & $0.78 \pm 0.44$ & $0.01 \pm 0.32$ \\
\hline Swamp Sparrow & Melospiza georgiana & 40440 & $32^{\circ}$ & $-1.28 \pm 0.48$ & $-0.12 \pm 0.31$ \\
\hline Eastern Meadowlark & Sturnella magna & 14220 & $32^{\circ}$ & $1.79 \pm 0.62$ & $1.34 \pm 0.38$ \\
\hline Red-winged Blackbird & Agelaius phoeniceus & 235500 & $37^{\circ}$ & $-0.59 \pm 0.49$ & $4.01 \pm 0.85$ \\
\hline Common Grackle & Quiscalus quiscula & 225599 & $38^{\circ}$ & $-0.34 \pm 0.54$ & $0.98 \pm 0.5$ \\
\hline Orange-crowned Warbler & Leiothlypis celata & 2159 & $29^{\circ}$ & $0.17 \pm 0.52$ & $0.89 \pm 0.31$ \\
\hline Common Yellowthroat & Geothlypis trichas & 53110 & $28^{\circ}$ & $-0.05 \pm 0.39$ & $0.07 \pm 0.15$ \\
\hline Palm Warbler & Setophaga palmarum & 7992 & $28^{\circ}$ & $-1.53 \pm 0.4$ & $-1.03 \pm 0.36$ \\
\hline Yellow-rumped Warbler & Setophaga coronata & 82918 & $30^{\circ}$ & $-0.67 \pm 0.74$ & $0.34 \pm 0.28$ \\
\hline
\end{tabular}




\section{References}

Adriaensen, F., P. Ulenaers, and A. A. Dhondt. 1993. Ringing recoveries and the increase in numbers of European Great Crested Grebes Podiceps cristatus. Ardea 81:59-70.

Ahas, R. 1999. Long-term phyto-, ornitho- and ichthyophenological time-series analyses in Estonia. International Journal of Biometeorology 42:119-123.

Berteaux, D., D. Réale, A. G. McAdam, and S. Boutin. 2004. Keeping pace with fast climate change: can arctic life count on evolution? Integrative and Comparative Biology 44:140.

Berthold, P. 1991. Patterns of avian migration in light of current global greenhouse effects: A central European perspective. In Proceedings of the 20th International Ornithological Congress, pages 780-786, Christchurch, New Zealand.

Berthold, P., E. Gwinner, and E. Sonnenschein. 2003. Avian migration. Springer-Verlag, Berlin, Germany.

Both, C. 2007. Comment on" Rapid Advance of Spring Arrival Dates in Long-Distance Migratory Birds". Science 315:598-598.

Both, C., S. Bouwhuis, C. M. Lessells, and M. E. Visser. 2006. Climate change and population declines in a long-distance migratory bird. Nature 441:81-83.

Both, C. and L. te Marvelde. 2007. Climate change and timing of avian breeding and migration throughout Europe. Climate Research 35:93-105.

Both, C., M. Van Asch, R. G. Bijlsma, A. B. Van Den Burg, and M. E. Visser. 2009. Climate change and unequal phenological changes across four trophic levels: constraints or adaptations? Journal of Animal Ecology 78:73-83.

Both, C. and M. E. Visser. 2001. Adjustment to climate change is constrained by arrival date in a long-distance migrant bird. Nature 411:296-298.

Brown, C. R. and M. B. Brown. 2000. Weather-mediated natural selection on arrival time in cliff swallows (Petrochelidon pyrrhonota). Behavioral Ecology and Sociobiology 47:339-345.

Bulmer, M. G. 1980. The mathematical theory of quantitative genetics. Clarendon Press, Oxford, UK.

Butcher, G. S., M. R. Fuller, L. S. McAllister, and P. H. Geissler. 1990. An evaluation of the Christmas Bird Count for monitoring population trends of selected species. Wildlife Society Bulletin (19732006) 18:129-134.

Butler, C. J. 2003. The disproportionate effect of global warming on the arrival dates of shortdistance migratory birds in North America. Ibis 145:484-495.

Chmura, H. E., H. M. Kharouba, J. Ashander, S. M. Ehlman, E. B. Rivest, and L. H. Yang. 2019. The mechanisms of phenology: the patterns and processes of phenological shifts. Ecological Monographs 89:e01337.

Cyr, A. and J. Larivée. 1979. Significance of data collected on birds in Quebec, Canada, by nonstandardized methods. In H. Oelke, editor, Proceedings of the VI International Congress on Bird Census Work, pages 66-76, Gröttingen, Germany. 
Cyr, A. and J. Larivée. 1993. Monitoring bird population changes with ÉPOQ (Étude des populations d'oiseaux du Québec: studies of bird populations in Quebec): twenty years trends. In M. Cadman and J. B. Falls, editors, Monitoring bird populations: the Canadian experience (Occasional paper no. 95), pages 40-42. Canadian Wildlife Service, Guelph, ON, Canada.

eBird Basic Dataset. 2021. eBird Basic Dataset, February 2021 release. Cornell Lab of Ornithology, Ithaca, NY, USA.

Felsenstein, J. 1985. Phylogenies and the Comparative Method. The American Naturalist 125:1-15.

Francoeur, X. W. 2012. Effets des changements climatiques sur la phénologie printanière de lavifaune du Québec. M. sc. thesis, Université du Québec à Rimouski.

Freckleton, R. P., P. H. Harvey, and M. Pagel. 2002. Phylogenetic analysis and comparative data: A test and review of evidence. American Naturalist 160:712-726.

Gienapp, P., R. Leimu, and J. Merilä. 2007. Responses to climate change in avian migration timemicroevolution versus phenotypic plasticity. Climate Research 35:25-35.

Gill, J. A., J. A. Alves, W. J. Sutherland, G. F. Appleton, P. M. Potts, and T. G. Gunnarsson. 2014. Why is timing of bird migration advancing when individuals are not? Proceedings of the Royal Society B: Biological Sciences 281:20132161.

Goodenough, A. E., S. M. Fairhurst, J. B. Morrison, M. Cade, P. J. Morgan, and M. J. Wood. 2015. Quantifying the robustness of first arrival dates as a measure of avian migratory phenology. Ibis 157:384-390.

Gordo, O. 2007. Why are bird migration dates shifting? A review of weather and climate effects on avian migratory phenology. Climate Research 35:37-58.

Grafen, A. 1989. The phylogenetic regression. Philosophical Transactions of the Royal Society of London. Series B, Biological Sciences 326:119-157.

Gwinner, E. 2003. Circannual rhythms in birds. Current Opinion in Neurobiology 13:770-778.

Gwinner, E. and B. Helm. 2003. Circannual and circadian contributions to the timing of avian migration. In P. Berthold and E. Gwinner, editors, Avian migration, pages 81-95. Springer-Verlag, Heidelberg, Germany.

Haest, B., O. Hüppop, and F. Bairlein. 2018. Challenging a 15yearold claim: The North Atlantic Oscillation index as a predictor of spring migration phenology of birds. Global change biology 24:1523-1537.

Hansen, J., M. Sato, R. Ruedy, K. Lo, D. W. Lea, and M. Medina-Elizade. 2006. Global temperature change. Proceedings of the National Academy of Sciences 103:14288-14293.

Harvey, P. H. and M. D. Pagel. 1991. The comparative method in evolutionary biology. Oxford University Press, Oxford, UK.

Ho, L. S. T. and C. Ané. 2014. A Linear-time algorithm for Gaussian and non-Gaussian trait evolution models. Systematic Biology 63:397-408. 
Horton, K. G., F. A. La Sorte, D. Sheldon, T.-Y. Lin, K. Winner, G. Bernstein, S. Maji, W. M. Hochachka, and A. Farnsworth. 2020. Phenology of nocturnal avian migration has shifted at the continental scale. Nature Climate Change 10:63-68.

Hurlbert, A. H. and Z. Liang. 2012. Spatiotemporal variation in avian migration phenology: citizen science reveals effects of climate change. PLoS One 7:e31662.

Hüppop, O. and K. Hüppop. 2011. Bird migration on Helgoland: the yield from 100ăyears of research. Journal of Ornithology 152:25-40.

IPCC, editor. 2013. Climate Change 2013: The Physical Science Basis. Contribution of Working Group I to the Fourth Assessment. Report of the Intergovernmental Panel on Climate Change. Cambridge University Press, Cambridge, UK.

Jetz, W., G. H. Thomas, J. B. Joy, K. Hartmann, and A. O. Mooers. 2012. The global diversity of birds in space and time. Nature 491:444-448.

Jetz, W., G. H. Thomas, J. B. Joy, D. W. Redding, K. Hartmann, and A. O. Mooers. 2014. Global distribution and conservation of evolutionary distinctness in birds. Current Biology 24:919-930.

Jonzén, N., A. Linden, T. Ergon, E. Knudsen, J. O. Vik, D. Rubolini, D. Piacentini, C. Brinch, F. Spina, and L. Karlsson. 2006. Rapid advance of spring arrival dates in long-distance migratory birds. Science 312:1959-1961.

Jonzén, N., A. Lindén, T. Ergon, E. Knudsen, J. O. Vik, D. Rubolini, D. Piacentini, C. Brinch, F. Spina, and L. Karlsson. 2007. Response to Comment on" Rapid Advance of Spring Arrival Dates in Long-Distance Migratory Birds". Science 315:598-598.

Kelly, J. F., K. G. Horton, P. M. Stepanian, K. de Beurs, S. Pletschet, T. Fagin, E. S. Bridge, and P. B. Chilson. 2017. The pulse of the planet: measuring and interpreting phenology of avian migration pages $401-425$.

Knudsen, E., A. Lindén, C. Both, N. Jonzén, F. Pulido, N. Saino, W. J. Sutherland, L. A. Bach, T. Coppack, and T. Ergon. 2011. Challenging claims in the study of migratory birds and climate change. Biological Reviews 86:928-946.

Knudsen, E., A. Lindén, T. Ergon, N. Jonzén, J. O. Vik, J. Knape, J. E. Røer, and N. C. Stenseth. 2007. Characterizing bird migration phenology using data from standardized monitoring at bird observatories. Climate Research 35:59-77.

Koleek, J., P. Adamík, and J. Reif. 2020. Shifts in migration phenology under climate change: temperature vs. abundance effects in birds. Climatic Change pages 1-18.

Leech, D. and H. Crick. 2007. Influence of climate change on the abundance, distribution and phenology of woodland bird species in temperate regions. Ibis 149:128-145.

Lehikoinen, E. and T. H. Sparks. 2010. Changes in migration. In A. P. Møller, W. Fiedler, and P. Berthold, editors, Effects of climate change on birds, pages 89-112. Oxford University Press, Oxford, UK.

Lehikoinen, E., T. H. Sparks, and M. alakeviius. 2004. Arrival and departure dates. Advances in Ecological Research 35:1-31. 
Lenth, R. V. 2021. emmeans: Estimated Marginal Means, aka Least-Squares Means. R package version 1.5.5-1.

Mason, C. F. 1995. Long-term trends in the arrival dates of spring migrants. Bird Study 42:182-189.

Mathot, K. J., J. Wright, B. Kempenaers, and N. J. Dingemanse. 2012. Adaptive strategies for managing uncertainty may explain personality-related differences in behavioural plasticity. Oikos 121:1009-1020.

Miller-Rushing, A. J., T. L. Lloyd-Evans, R. B. Primack, and P. Satzinger. 2008. Bird migration times, climate change, and changing population sizes. Global Change Biology 14:1959-1972.

MillerRushing, A. J., D. W. Inouye, and R. B. Primack. 2008. How well do first flowering dates measure plant responses to climate change? The effects of population size and sampling frequency. Journal of Ecology 96:1289-1296.

Moussus, J., R. Julliard, and F. Jiguet. 2010. Featuring 10 phenological estimators using simulated data. Methods in Ecology and Evolution 1:140-150.

Møller, A. P. 2004. Protandry, sexual selection and climate change. Global Change Biology 10:20282035.

Møller, A. P., D. Rubolini, and E. Lehikoinen. 2008. Populations of migratory bird species that did not show a phenological response to climate change are declining. Proceedings of the National Academy of Sciences, U.S.A. 105:16195-16200.

Newson, S. E., N. J. Moran, A. J. Musgrove, J. W. PearceHiggins, S. Gillings, P. W. Atkinson, R. Miller, M. J. Grantham, and S. R. Baillie. 2016. Longterm changes in the migration phenology of UK breeding birds detected by largescale citizen science recording schemes. Ibis 158:481-495.

Newton, I. 2008. The migration ecology of birds. Academic Press, London, UK.

Paradis, E. and K. Schliep. 2018. ape 5.0: an environment for modern phylogenetics and evolutionary analyses in R. CRAN.

Parmesan, C. 2007. Influences of species, latitudes and methodologies on estimates of phenological response to global warming. Global Change Biology 13:1860-1872.

Post, E., B. A. Steinman, and M. E. Mann. 2018. Acceleration of phenological advance and warming with latitude over the past century. Scientific Reports 8:3927.

Pulido, F. and P. Berthold. 2004. Microevolutionary response to climatic change. Advances in Ecological Research 35:151-183.

Pulido, F., P. Berthold, G. Mohr, and U. Querner. 2001. Heritability of the timing of autumn migration in a natural bird population. Proceedings of the Royal Society of London. Series B: Biological Sciences 268:953-959.

R Core Team. 2020. R: A Language and Environment for Statistical Computing. R Foundation for Statistical Computing, Vienna, Austria. 
Radchuk, V., T. Reed, C. Teplitsky, M. van de Pol, A. Charmantier, C. Hassall, P. Adamík, F. Adriaensen, M. P. Ahola, P. Arcese, J. Miguel Avilés, J. Balbontin, K. S. Berg, A. Borras, S. Burthe, J. Clobert, N. Dehnhard, F. de Lope, A. A. Dhondt, N. J. Dingemanse, H. Doi, T. Eeva, J. Fickel, I. Filella, F. Fossøy, A. E. Goodenough, S. J. G. Hall, B. Hansson, M. Harris, D. Hasselquist, T. Hickler, J. Joshi, H. Kharouba, J. G. Martínez, J.-B. Mihoub, J. A. Mills, M. Molina-Morales, A. Moksnes, A. Ozgul, D. Parejo, P. Pilard, M. Poisbleau, F. Rousset, M.-O. Rödel, D. Scott, J. C. Senar, C. Stefanescu, B. G. Stokke, T. Kusano, M. Tarka, C. E. Tarwater, K. Thonicke, J. Thorley, A. Wilting, P. Tryjanowski, J. Merilä, B. C. Sheldon, A. Pape Møller, E. Matthysen, F. Janzen, F. S. Dobson, M. E. Visser, S. R. Beissinger, A. Courtiol, and S. Kramer-Schadt. 2019. Adaptive responses of animals to climate change are most likely insufficient. Nature Communications 10:3109.

Root, T. L., D. P. MacMynowski, M. D. Mastrandrea, and S. H. Schneider. 2005. Human-modified temperatures induce species changes: joint attribution. Proceedings of the National Academy of Sciences 102:7465-7469.

Rubolini, D., A. P. Møller, K. Rainio, and E. Lehikoinen. 2007. Intraspecific consistency and geographic variability in temporal trends of spring migration phenology among European bird species. Climate Research 35:135-146.

Saino, N., R. Ambrosini, D. Rubolini, J. von Hardenberg, A. Provenzale, K. Hüppop, O. Hüppop, A. Lehikoinen, E. Lehikoinen, and K. Rainio. 2011. Climate warming, ecological mismatch at arrival and population decline in migratory birds. Proceedings of the Royal Society B: Biological Sciences 278:835-842.

Saino, N., D. Rubolini, E. Lehikoinen, L. V. Sokolov, A. Bonisoli-Alquati, R. Ambrosini, G. Boncoraglio, and A. P. Møller. 2009. Climate change effects on migration phenology may mismatch brood parasitic cuckoos and their hosts. Biology Letters 5:539-541.

Saino, N., T. Szep, M. Romano, D. Rubolini, F. Spina, and A. P. Møller. 2004. Ecological conditions during winter predict arrival date at the breeding quarters in a trans-Saharan migratory bird. Ecology Letters 7:21-25.

Sauer, J. R., J. E. Hines, J. E. Fallon, K. L. Pardieck, J. D. J. Ziolkowski, and W. A. Link. 2014. The North American Breeding Bird Survey, Results and Analysis 1966 - 2013. Version 01.30.2015. USGS Patuxent Wildlife Research Center, Laurel, MD, USA.

Settele, J., R. Scholes, R. Betts, S. Bunn, P. Leadley, D. Nepstad, J. Overpeck, and M. A. Taboada. 2014. Terrestrial and inland water systems. In C. Field, V. Barros, D. Dokken, K. Mach, M. Mastrandrea, T. Bilir, M. Chatterjee, K. Ebi, Y. Estrada, R. Genova, B. Girma, E. Kissel, A. Levy, S. MacCracken, P. Mastrandrea, and L. White, editors, Climate Change 2014: Impacts, Adaptation, and Vulnerability. Part A: Global and Sectoral Aspects. Contribution of Working Group II to the Fifth Assessment Report of the Intergovernmental Panel on Climate Change, pages 271-359. Cambridge University Press, Cambridge, UK.

Sparks, T., D. R. Roberts, and H. Crick. 2001. What is the value of first arrival dates of spring migrants in phenology? Avian Ecological Behaviour 7:75-85.

Sparks, T. H. 1999. Phenology and the changing pattern of bird migration in Britain. International Journal of Biometeorology 42:134-138. 
Stenseth, N., G. Ottersen, J. Hurrell, A. Mysterud, M. Lima, K. Chan, N. Yoccoz, and B. Adlandsvik. 2003. Studying climate effects on ecology through the use of climate indices: the North Atlantic Oscillation, El Nino Southern Oscillation and beyond. Proceedings of the Royal Society B: Biological Sciences 270:2087-2096.

Sullivan, A. R., D. J. Flaspohler, R. E. Froese, and D. Ford. 2016. Climate variability and the timing of spring raptor migration in eastern North America. Journal of Avian Biology 47:208-218.

Sullivan, B., C. Wood, M. Iliff, R. Bonney, D. Fink, and S. Kelling. 2009. eBird: a citizen-based bird observation network in the biological sciences. Biological Conservation 142:2282-2292.

Thackeray, S. J., P. A. Henrys, D. Hemming, J. R. Bell, M. S. Botham, S. Burthe, P. Helaouet, D. G. Johns, I. D. Jones, and D. I. Leech. 2016. Phenological sensitivity to climate across taxa and trophic levels. Nature 535:241-245.

Thomas, D. W., J. Blondel, P. Perret, M. M. Lambrechts, and J. R. Speakman. 2001. Energetic and fitness costs of mismatching resource supply and demand in seasonally breeding birds. Science 291:2598-2600.

Tryjanowski, P., S. Kuniak, and T. H. Sparks. 2005. What affects the magnitude of change in first arrival dates of migrant birds? Journal of Ornithology 146:200-205.

Van Buskirk, J., R. S. Mulvihill, and R. C. Leberman. 2012. Phenotypic plasticity alone cannot explain climateinduced change in avian migration timing. Ecology and Evolution 2:2430-2437.

Visser, M. E. and C. Both. 2005. Shifts in phenology due to global climate change: the need for a yardstick. Proceedings of the Royal Society B: Biological Sciences 272:2561-2569. 